\title{
Research Regarding the Influence of Drying Agent's Speed and Temperature on the Work Process of Corn Dehydration
}

\author{
Vlad-Nicolae ARSENOAIA ${ }^{1 *}$, Ioan ȚENU ${ }^{1}$, Radu ROȘCA ${ }^{1}$, Petru CÂRLESCU ${ }^{1}$ and Cezara ZĂPODEANU ${ }^{1}$ \\ ${ }^{1}$ Faculty of Agriculture, University of Agricultural Sciences and Veterinary Medicine "Ion Ionescu de la \\ Brad", Iaşi, Romania \\ *Corresponding author: vlad_arsenoaia@yahoo.com
}

Bulletin USAMV series Agriculture 72(2)/2015

Print ISSN 1843-5246; Electronic ISSN 1843-5386

DOI 10.15835/buasvmcn-agr: 11515

\begin{abstract}
Introduction: For the proper progression of the work process for cereal drying it is necessary that the distribution of the termic agent should be uniform and steady through the product layer, so that the variation of the product's humidity and temperature could be similar in all the layer's spots.

Aims: The purpose of this paper is to obtain a uniform distribution of heat in the product along with a close variation of its humidity on the layer's thickness.

Materials and Methods: In order to achieve those proposed, corn seeds with humidities between 16-25\% were subjected successively to be dried, in three adjoining cells with a total thickness of $150 \mathrm{~mm}$. To fulfill the objective, there was an installation designed and built for dehydration of cereal seeds in laboratory conditions. By varying the speed and the temperature of the termic agent, were studied a total of 80 experimental variants. During the research, was monitored the influence of the structural and functional parameters of the installation for dehydration on the variation of humidity.

Results: The results of the experimental researches highlight the conversely proportional variation of moisture in the three layers while increasing the drying agent's speed and temperature. Values of layers humidities have varied evenly for temperatures up to $60^{\circ} \mathrm{C}$.

Conclusion: In the present research work, we demonstrated that with decreasing humidity the porosity increases in the product layer, the drying agent speed increases, the drying agent temperature decreases, and the drying agent humidity increases.
\end{abstract}

Keywords: corn, drying, parameters.

\section{INTRODUCTION}

Drying cereal grains removes many dangers of harvesting and storage of agricultural products with high humidity.

The need for rigorous stewardship of thermal regime of grain dryers requires technicalfunctional knowledge of plants used for drying seeds and presents a great importance because it allows to obtain a global picture regarding certain categories of performance.

In the past, efforts have been made to experimentally study the drying process of corn seed.
So far, studies have been focused on the analysis of fluidized bed drying process, microwaveassisted foam drying, and extractability of saltsoluble protein.

A batch type fluidized bed dryer was designed and constructed in order to investigate drying performance of a batch type fluidized bed drying process of corn and unshelled pistachio nut regarding to energetic and exergetic efficiencies. A series of experiments were carried out for the purpose in the covered range of $50{ }^{\circ} \mathrm{C}$ ? $\mathrm{T}$ ? 75 ${ }^{\circ} \mathrm{C}$ and $6.87 \mathrm{~m} / \mathrm{s}$ ? Um $10.86 \mathrm{~m} / \mathrm{s}$. (Özahi and Demir, 2014) 
To improve the industrial utilization of corn soaking water, the yeast protein powder was produced by microwave-assisted foam drying. Firstly, preparation experiments were carried out, which included the foaming characteristic experiments of fermentation broth and that about the effects of carbon and nitrogen ratio on solid content in the fermentation broth. Secondly, the drying characteristics experiment of corn soaking water was studied, which selected the microwave power, material amount and thickness as the influencing factors for the single experiment. The results showed that the final moisture content and drying rate were significantly affected by those factors. (Qiang et al., 2011)

The effect of heat treatments (drying and hydrothermal treatment) on the extractability of salt-soluble protein (SSP) was assessed using Promatest methodology for corn kernels heated between $60{ }^{\circ} \mathrm{C}$ and $120{ }^{\circ} \mathrm{C}$. During drying, the evolution of the grain moisture content is fitted using the analytical solution of Fick equation developed by Crank (1979) for spherical material. The decrease of extractible salt-soluble protein during heating is forecasted using a first and a second order ordinary differential equation. It was found that temperature; moisture content and time of processing greatly influence the kinetic denaturation of SSP of corn kernels. The evolution of extractible SSP content of corn kernels during drying at high temperature is more correctly described with second order kinetic than with the first order kinetic reaction. (Odjo et al., 2011)

The effects of air drying temperature on the wet-milling performance and the proteins solubility indexes were investigated for corn kernels dried between $54{ }^{\circ} \mathrm{C}$ and $130{ }^{\circ} \mathrm{C}$. It was observed that when the drying temperature increases, the starch yield drops significantly. The gluten recovered increased abruptly for drying temperatures up to $80{ }^{\circ} \mathrm{C}$. The albumin, globulin and zein solubility indexes decreased continuously when corn drying temperatures increased. According to the temperatures used, the starch yield, the gluten recovered and the saltsoluble proteins solubility indexes were adjusted satisfactorily by using a two asymptotic logistic model. (Malumba et al., 2009)

Drying characteristics of shelled corn with an initial moisture content of $26 \%$ dry basis (db) was studied in a fluidized bed dryer assisted by microwave heating. Four air temperatures (30, 40,50 and $60{ }^{\circ} \mathrm{C}$ ) and five microwave powers $(180,360,540,720$ and $900 \mathrm{~W})$ were studied. Several experiments were conducted to obtain data for sample moisture content versus drying time. The results showed that increasing the drying air temperature resulted in up to $5 \%$ decrease in drying time while in the microwaveassisted fluidized bed system, the drying time decreased dramatically up to $50 \%$ at a given and corresponding drying air temperature at each microwave energy level. As a result, addition of microwave energy to the fluidized bed drying is recommended to enhance the drying rate of shelled corn. (Momenzadeh et al., 2009)

The purpose of this paper is to obtain a uniform distribution of heat in the product layers along with a close variation of its humidity on the layer's thickness.

For the experiment corn seed were submitted to dehydration in three adjoining cells $(50 \mathrm{~mm}$ thickness each) with four initial moisture contents $(25,22,19,16 \%)$ through five temperatures $(40$, $\left.50,60,70,80^{\circ} \mathrm{C}\right)$ and four fan speeds $(1,1.5,2,2.5$ $\mathrm{m} / \mathrm{s})$.

\section{MATERIALS AND METHODS}

The heat is brought into the product layer by means of hot air (convection). Water vapor produced are taken out of the air, which is the mass transfer medium.

Once the heat penetrates the grain mass, the mass transfer (water) starts inside the product to its surface. The water can easily reach the surface of the product or product easily occurs the phenomenon of evaporation.

The water then moves under the influence of capillary forces and due to shrinkage of the product during dehydration.

Towards the end of the drying process, the water transfer is slower because of the dried layer formed on the surface of the product.

The experiences of drying products were made in the Department of Agricultural Mechanization of the University of Agricultural Sciences and Veterinary Medicine "Ion Ionescu de la Brad", Iaşi, Romania, using laboratory facilities for drying agricultural products. The laboratory dryer allows control and monitoring of the drying process parameters that can be chosen by the user before or during the drying process. 
The dryer (Fig. 1.) is equipped with an automation system PID controller (Proportional Integral Derivative Controller), which controls via a thermostat, the independent heating and constant air temperature. A temperature sensor located in the drying box controls the temperature of drying.

In Fig. 2. is presented the box for cereal seed dehydration. It consists of eight cells $(50 \mathrm{~mm}$ wide each) which are delimited by nine stainless steel sieves.

The technical characteristics of the dryer are shown in the table below (Tab. 1.).
Humidity of the drying agent is monitored using moisture sensors mounted in two positions: before the cereal layer and after.

The speed of the drying agent is controlled by the automation system, by varying fan speed. The control of speed of the drying agent is made by using the hot wire anemometer TROTEC TA 300 shown in Fig. 3. with technical specifications presented in Tab. 2.

During the research, we observed the influence of the structural and functional parameters of the installation for drying, the variation of humidity

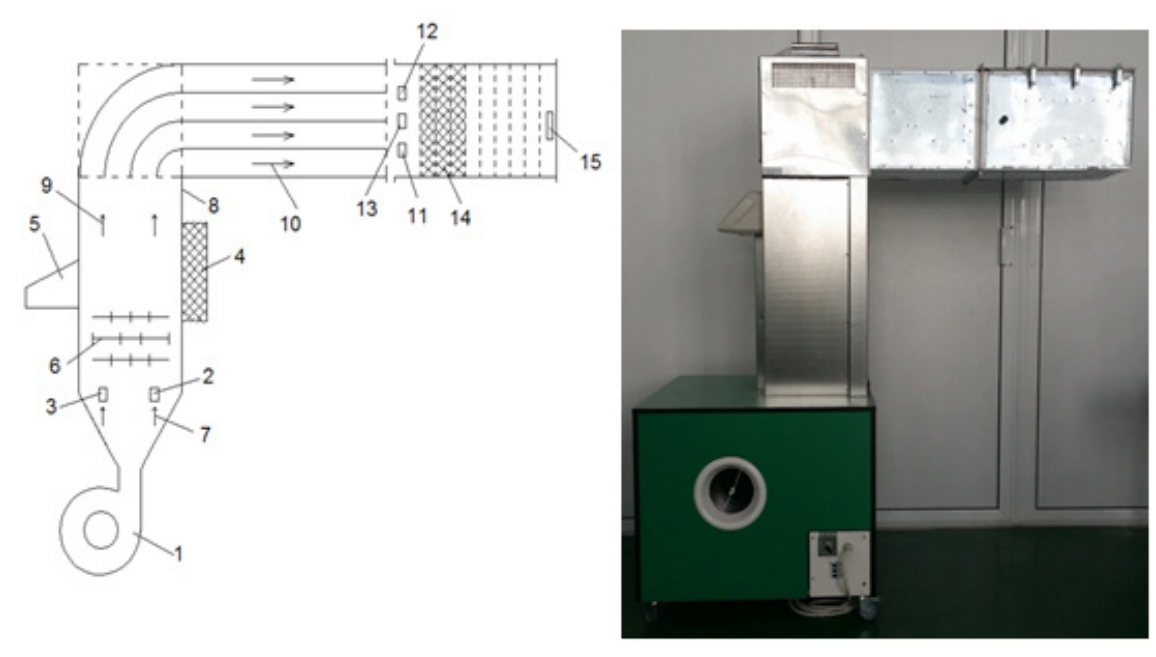

Fig. 1. Laboratory dryer scheme: 1 - fan; 2 - temperature sensor; 3 - speed sensor; 4 - isolating layer; 5 - control panel; 6 - electrical resistance; 7 - cold air; 8 - body; 9 - hot air; 10 - drying agent; 11 - temperature sensor; 12 - humidity sensor; 13 - speed sensor; 14 drying cells; 15 - moisture sensor for the used drying agent.

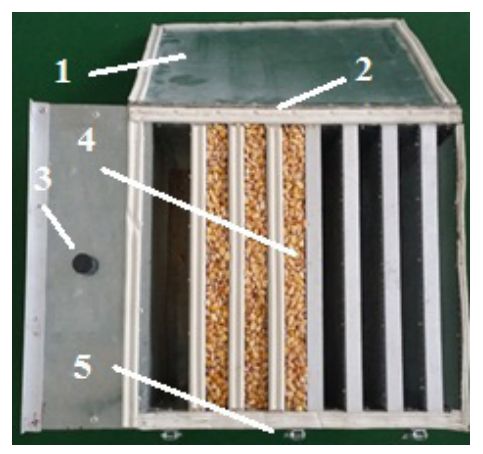

Fig. 2. Cereal seed drying box: 1 - cover; 2 - seals; 3 - hole for introducing measuring probes; 4 drying cells separated by steel sieves; 5 - sealing cap system.

Tab. 1. Dryer technical features

\begin{tabular}{ccc}
\hline No. & Technical features & Values \\
\hline 1 & Reaching drying temperature & $110^{\circ} \mathrm{C}$ in $\operatorname{max~} 20 \mathrm{~min}$. \\
\hline 2 & Thermostatic temperature programming & $+5^{\circ} \mathrm{C} . . .+120^{\circ} \mathrm{C}$ \\
\hline 3 & Programming the thermostat time & $0 \ldots 999 \mathrm{~min}$. \\
\hline 4 & Thermostatic accuracy & $+/-2^{\circ} \mathrm{C}$ \\
\hline 5 & Temperature sensor input and output & PT100 \\
\hline 6 & Humidity Sensor input and output & SHT $25+/-2 \%$. \\
\hline 7 & Power consumption up to the programmed temperature & $3500 \mathrm{~W}$ \\
\hline 8 & Power consumption for temperature maintenance scheduled & max.550W \\
\hline 10 & Air flow resistance before heating & min. $900 \mathrm{~m} \mathrm{~m}^{3} / \mathrm{h}$ \\
\hline 11 & Dryer inlet air pressure & min. $980 \mathrm{~Pa}$ \\
\hline
\end{tabular}




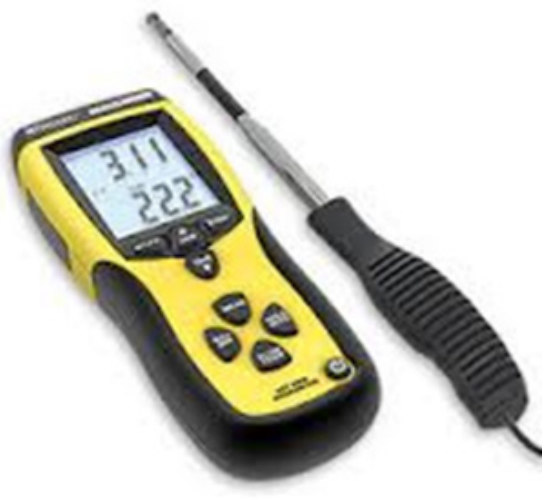

Fig. 3. Hot wire anemometer

Tab. 2. Anemometer technical features

\begin{tabular}{ccc}
\hline No. & Technical features & Values \\
\hline 1 & Measuring range & 0.1 to $30 \mathrm{~m} / \mathrm{s}$ \\
\hline 2 & Accuracy & $\pm 0.1 \mathrm{~m} / \mathrm{s}$ \\
\hline 3 & Measuring principle & hot wire \\
\hline
\end{tabular}

Tab. 3. Experimental variants in the three layers of seeds up to the humidity of $14 \%$.

\section{RESULTS AND DISCUSSION}

The drying time of the mass of grains largely depends on the initial moisture content. The influence of heat can be favorable only if applied wisely regarding the correlation of the following three factors: the temperature of the drying agent, its speed and temperature of the grain seed.

Furthermore will be presented the proposed alternatives for drying corn seeds. In Tab. 3. are presented the experimental variants for drying corn seeds for consumption.

During the drying process, humidity vary continuously downwards after complex laws. In order to maintain a high proportion of the qualities as the initial seed is required a close correlation between the temperature and humidity of the drying agent.

In order to achieve those proposed were subjected successively corn seeds to be dried with $25,22,19,16 \%$ humidity in the three adjoining cells with a total thickness of $150 \mathrm{~mm}$.

\begin{tabular}{|c|c|c|c|c|c|c|}
\hline $\begin{array}{c}\text { Experimental } \\
\text { variant }\end{array}$ & $\begin{array}{c}\text { Drying agent } \\
\text { temperature } \\
\left({ }^{\circ} \mathrm{C}\right)\end{array}$ & $\begin{array}{c}\text { Drying agent } \\
\text { speed } \\
(\mathrm{m} / \mathrm{s})\end{array}$ & $\begin{array}{c}\text { Drying time } \\
\text { for initial } 16 \% \\
\text { humidity (min) }\end{array}$ & $\begin{array}{c}\text { Drying time } \\
\text { for initial } 19 \% \\
\text { humidity (min) }\end{array}$ & $\begin{array}{c}\text { Drying time } \\
\text { for initial } 22 \% \\
\text { humidity (min) }\end{array}$ & $\begin{array}{c}\text { Drying time } \\
\text { for initial } 25 \% \\
\text { humidity (min) }\end{array}$ \\
\hline Vp1 & \multirow{4}{*}{40} & 1.0 & 65 & 104 & 116 & 149 \\
\hline Vp2 & & 1.5 & 60 & 100 & 109 & 138 \\
\hline Vp3 & & 2.0 & 34 & 58 & 49 & 76 \\
\hline Vp4 & & 2.5 & 11 & 16 & 23 & 36 \\
\hline Vp5 & \multirow{4}{*}{50} & 1.0 & 61 & 100 & 102 & 128 \\
\hline Vp6 & & 1.5 & 55 & 97 & 104 & 124 \\
\hline Vp7 & & 2.0 & 20 & 25 & 29 & 43 \\
\hline Vp8 & & 2.5 & 10 & 15 & 21 & 33 \\
\hline Vp9 & \multirow{4}{*}{60} & 1.0 & 30 & 40 & 70 & 95 \\
\hline Vp10 & & 1.5 & 20 & 28 & 34 & 53 \\
\hline Vp11 & & 2.0 & 8 & 16 & 15 & 39 \\
\hline Vp12 & & 2.5 & 7 & 14 & 14 & 31 \\
\hline Vp13 & \multirow{4}{*}{70} & 1.0 & 14 & 35 & 59 & 90 \\
\hline Vp14 & & 1.5 & 11 & 20 & 28 & 51 \\
\hline Vp15 & & 2.0 & 7 & 9 & 12 & 31 \\
\hline Vp16 & & 2.5 & 5 & 8 & 11 & 28 \\
\hline Vp17 & \multirow{4}{*}{80} & 1.0 & 8 & 33 & 51 & 83 \\
\hline Vp18 & & 1.5 & 6 & 14 & 21 & 50 \\
\hline Vp19 & & 2.0 & 4 & 8 & 10 & 29 \\
\hline Vp20 & & 2.5 & 4 & 7 & 10 & 27 \\
\hline
\end{tabular}


By varying the speed and temperature of the drying agent between 1 and $2.5 \mathrm{~m} / \mathrm{s}$ and between 40 and $80^{\circ} \mathrm{C}$ were studied a total of 20 experimental variations for each initial moisture content.

In Fig. 4., Fig. 5., Fig. 6., Fig. 7. final humidities are plotted for the three seed cells for each initial moisture content.

The graphic highlights the humidity of the first and second layer that dropped below $14 \%$ so that the humidity of $14 \%$ to be reached in the third layer. The low humidity of the first layer of $6 \%$

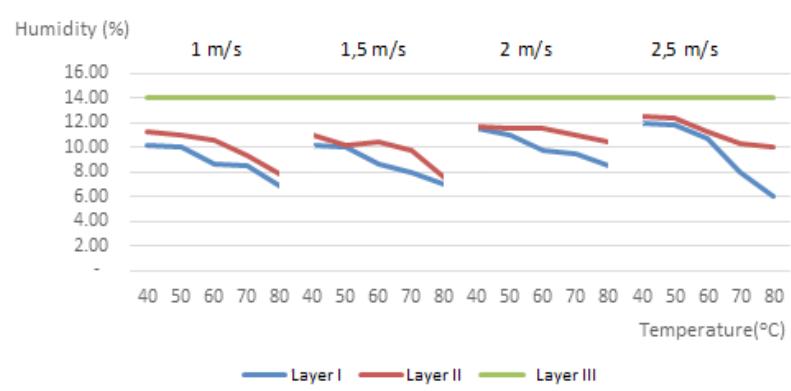

Fig. 4. Variation of final layers humidities for the initial moisture content of $25 \%$

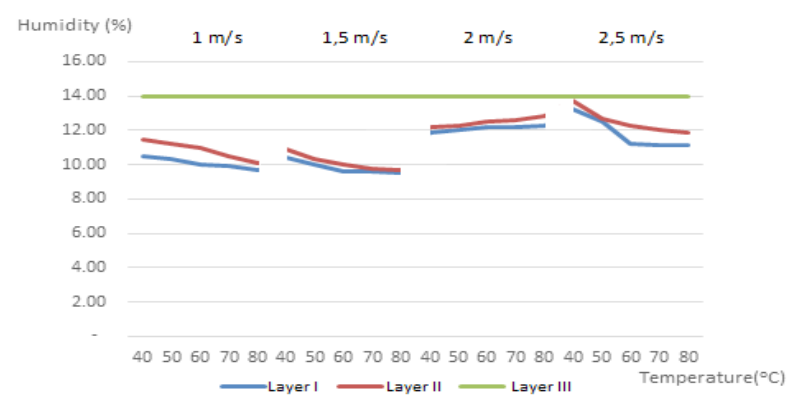

Fig. 6. Variation of final layers humidities for the initial moisture content of $19 \%$

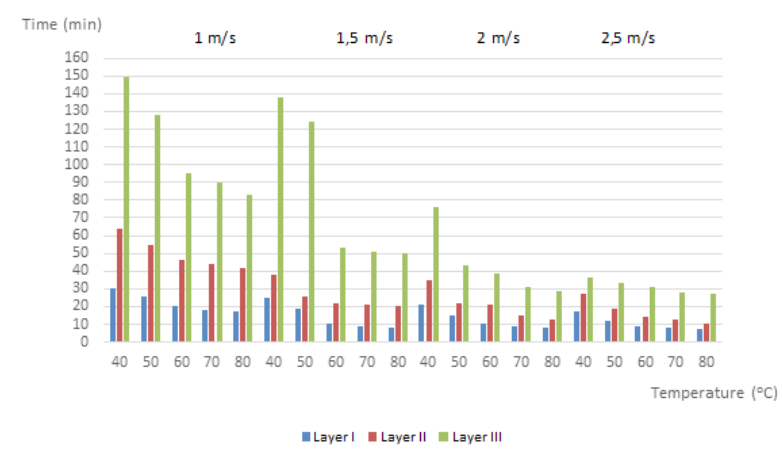

Fig. 8. Drying time variation in layers for the initial moisture content of $25 \%$ was achieved at the speed of the drying agent of $2,5 \mathrm{~m} / \mathrm{s}$ at $80^{\circ} \mathrm{C}$. For the speed of $1,5 \mathrm{~m} / \mathrm{s}$ and the temperature of $80{ }^{\circ} \mathrm{C}$, the humidity of the second layer recorded a value of 7,6\%.

The shortest drying time was 27 minutes, recorded at the speed of $2,5 \mathrm{~m} / \mathrm{s}$ at $80^{\circ} \mathrm{C}$, and the longest duration of 149 minutes was obtained for the speed of $1 \mathrm{~m} / \mathrm{s}$ at $40{ }^{\circ} \mathrm{C}$.

For the corn seed with $22 \%$ initial humidity, the drying time was between 10 and 116 minutes. The variation is similar to the previous situation,

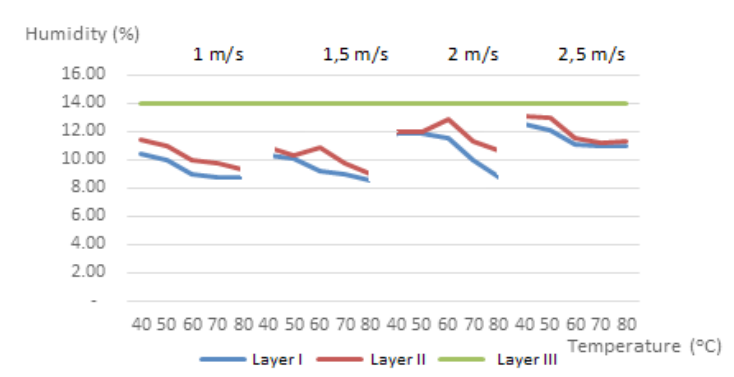

Fig. 5. Variation of final layers humidities for the initial moisture content of $22 \%$

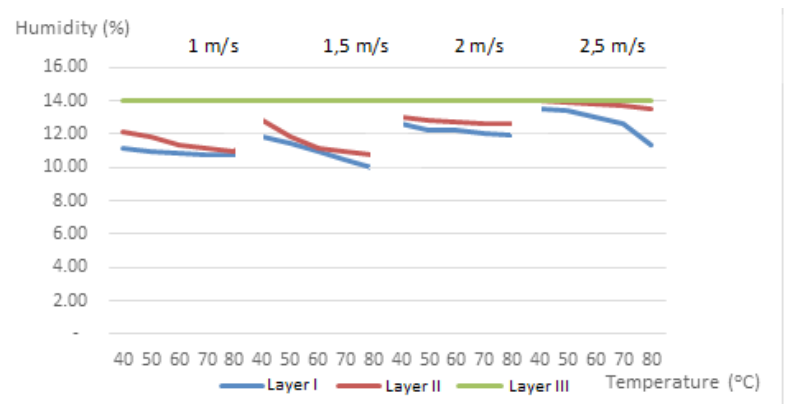

Fig. 7. Variation of final layers humidities for the initial moisture content of $16 \%$

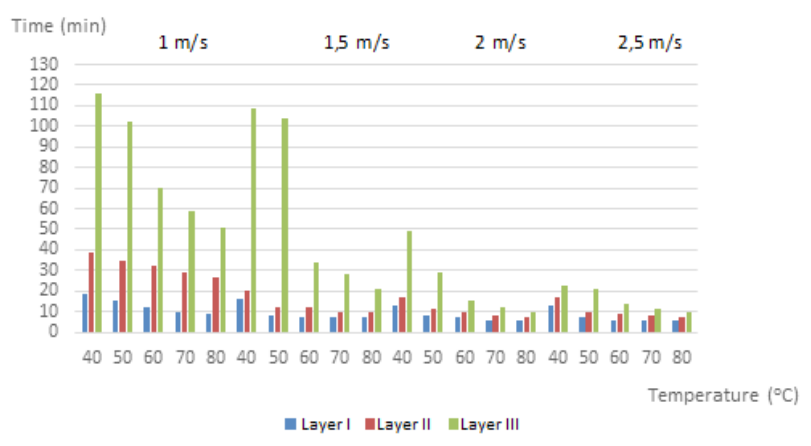

Fig. 9. Drying time variation in layers for the initial moisture content of $22 \%$ 
observing the same uniform drying at the speed of $2,5 \mathrm{~m} / \mathrm{s}$ at the temperature of $40^{\circ} \mathrm{C}$.

Regarding the drying of corn seed with 16 and $19 \%$ moisture, the final humidities are close in all layers. In this case there was a uniform drying for the speed profile of $2.5 \mathrm{~m} / \mathrm{s}$ regardless the temperature.

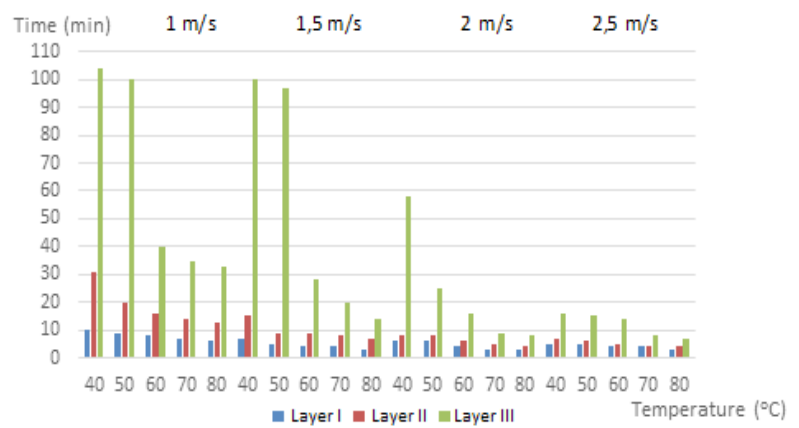

Fig. 10. Drying time variation in layers for the initial moisture content of $19 \%$

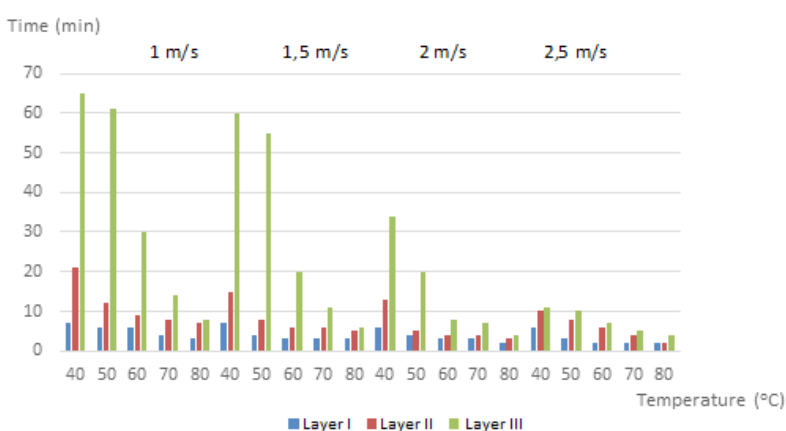

Fig. 11. Drying time variation in layers for the initial moisture content of $16 \%$

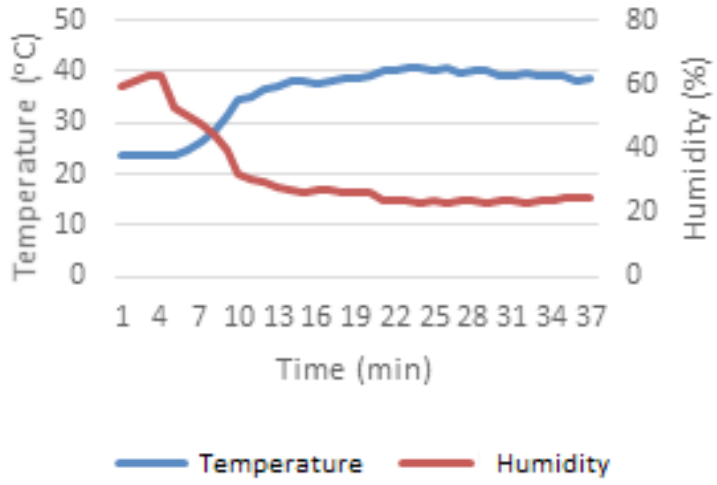

Fig. 13. Changes in temperature and humidity at the entrance of the drying agent
In Fig. 8., Fig. 9., Fig. 10., Fig. 11. are presented the variations of the drying time in all layers for the four initial moisture contents.

The variation of humidity in the layers was almost uniform for the speed of 2,5 m/s at the temperature of $40{ }^{\circ} \mathrm{C}$. The drying time up to $14 \%$ moisture was 37 minutes.

In Fig. 13. and Fig. 14. are presented the changes in temperature and humidity of the drying agent before and after the layers. Once the temperature reaches $40{ }^{\circ} \mathrm{C}$ it is maintained constant. The humidity drops to $23 \%$ and the value is maintained until the end of the drying process.

At the exit, the humidity follows the same downward trend in the first seven minutes due to the elimination of water. After the half of the drying time, it decreases with increasing the temperature.

\section{CONCLUSION}

Due to the advantages, in the recent years, the use of artificial drying of grain with both hot and cold air has grown up.

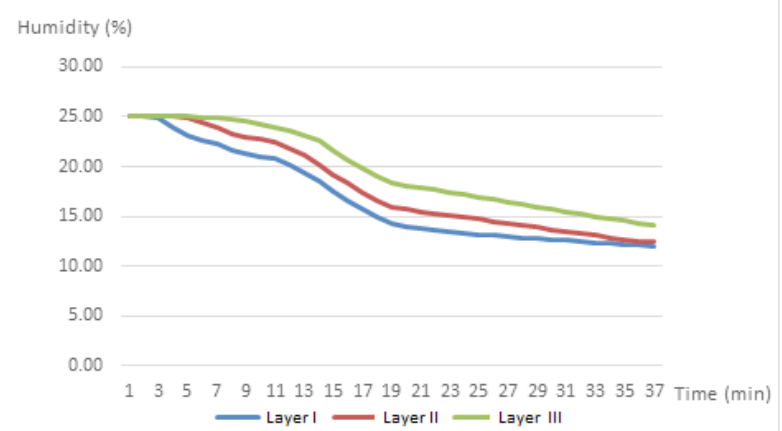

Fig. 12. Changes in moisture content during the drying process of corn with $25 \%$ humidity at a velocity of $2,5 \mathrm{~m} / \mathrm{s}$, at $40^{\circ} \mathrm{C}$

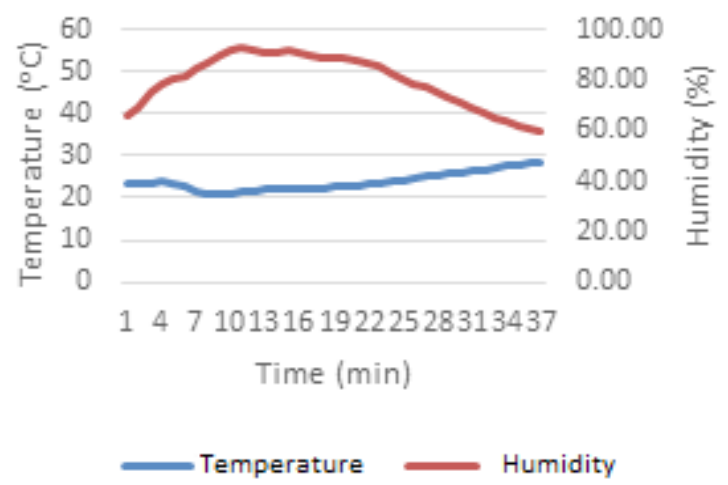

Fig. 14. Changes in temperature and humidity at the exit of the drying agent 
During the research, it was observed the influence of the structural and functional parameters of the installation for drying, the variation of humidity in the three layers of seeds, up to the humidity of $14 \%$.

The lowest humidity of the first layer of $6 \%$ was achieved at the speed of the drying agent of $2,5 \mathrm{~m} / \mathrm{s}$ at $80^{\circ} \mathrm{C}$.

High values for the duration of drying were recorded at the speeds of 1 and $1,5 \mathrm{~m} / \mathrm{s}$. The decreasing trend of the drying time stands out with increasing the speed and temperature.

It was found that the most uniform drying occurred at the speed of $2,5 \mathrm{~m} / \mathrm{s}$ at $40{ }^{\circ} \mathrm{C}$.

\section{REFERENCES}

1. Malumba P, Janas S, Masimango T, Sindic M, Deroanne C, Bera F (2009). Influence of drying temperature on the wet- milling performance and the proteins solubility indexes of corn kernels. Journal of Food Engineering 95:393-399.

2. Momenzadeh L, Zomorodian A, Mowla D (2009). Experimental and theoretical investigation of shelled corn drying in a microwave-assisted fluidized bed dryer using Artificial Neural Network. Food and Bioproducts Processing 89:15-21.

3. Odjo S, Malumba P, Dossou J, Janas S, Bera F (2011). Influence of drying and hydrothermal treatment of corn on the denaturation of salt-soluble proteins and color parameters. Journal of Food Engineering 109:561-570.

4. Özahi E, Demir H (2014). Drying performance analysis of a batch type fluidized bed drying process for corn and unshelled pistachio nut regarding to energetic and exergetic efficiencies. Measurement 60:85-96.

5. Qiang L, Yu S, Xiang-wen X, Qin-qin Z, Xian-zhe Z (2011). Drying Characteristics of Microwave-assisted Foam Drying of Corn Soaking Water. Journal of Northeast Agricultural University 20:53-59. 